\title{
Lifestyle Transformation in the Society
}

\author{
Abdul Latief \\ Al Asyariah Mandar University \\ Polewali Mandar, Indonesia
}

\author{
Muhajir Muhajir \\ Department of Pancasila and Civic Education \\ Muhammadiyah University of Makassar \\ Makasar, Indonesia \\ muhajir@ymail.com
}

\begin{abstract}
This advancement in information technology and globalization has caused such a profound change in the life of mankind with all its civilizations and cultures. These changes also have a profound impact on the transformation of existing values in society. So, great influence of technological progress to the cultural values embedded in society, both urban and rural (modernization). Technological advances such as radio, television, and even internet telephony not only hit the urban community but also has been enjoyed by people in remote villages. This research about the transformation of lifestyle in the society which aimed to describe the social lifestyle of people as the impact of information technology and to find out the factors affects the social lifestyle of the people. This research uses qualitative research method. Sampling technique is by determining its own characteristics and data collection techniques are done by using primary data and secondary data through observation, interview, and documentation. Based on the results of research, it can be concluded that the development of information technology has an impact on changes in social lifestyle in Tellulimpoe Village. The changes can be seen from the style of dress, speech, and attitude of society. In addition, the factors that influence social change in Tellulimpoe Village is with the existence of advanced formal education, open society system layer (open stratification).
\end{abstract}

Keywords - lifestyle; transformation; society

\section{INTRODUCTION}

Globalization with one feature of information technology has given all forms of convenience for Indonesia not only for the business sector, trade and also for the government [1]. The ease of accessing information and news due to information technology has changed the habits of the Indonesian people to communicate, which at first just face-to-face, can currently do even at a long distance, before the internet and the use of texting on cellular phones, people communicated face to face. Now, people can be in almost constant contact with each other through the Internet, cell phones, and other technological devices. However, this contact does not have the same physical element that face-to-face communication has [2].

However, every media that we use in life always brings influence to its users. Whether it's a positive influence or a negative influence we should be able to spread ourselves so as not to be harmed by users of the media. The rapid development of technology, especially in television media today can cause some influence on people's life especially for children [3]. The mindset of a child who has not been able to tell which one is right and which one is the cause of the child's behavior change. In general, children love watching action movies or movies that show fast movements with powerful sound effects. That's why they love to watch cartoons that contain some spectacular movements.

Social change is a symptom inherent in every society. Changes that occur within the community will cause a mismatch between the social elements that exist in the community, so it generates a pattern of life that does not to the function for the community concerned. A society that has reached a certain civilization means that it has undergone a long and meaningful cultural evolution to a certain degree that is recognized at the science and technology level and other cultural elements [4]. Thus, the community has undergone a meaningful process of social change, so that the standard of living is increasingly complex. The process cannot be separated from the various developments, changes, and growth that include aspects of demography, economics, organization, politics, science, technology and others. Social change will continue as long as there is interaction between human and inter-community. Social change occurs because of changes in elements that maintain the balance of society, such as changes in geographical, biological, economic, and cultural elements.

The purpose of this study will be describing that the current technological developments have brought changes to the process of globalization and culture in society to the cultural values of the people of Tellulimpoe Village. Lifestyle is a pattern of action that distinguishes between one person and another, which is in interaction with ways that may not be understood by those who do not live in modern society. In the development of lifestyle today is no longer a problem in certain circles.

The changes are made to adjust to the times. Due to the increasingly modernization of the village community, Villagers are always connoted with traditional traits, strong bonds with nature, tight bonding group, live well, working together.

\section{THEORETICAL}

Lifestyle is the lifestyle of a person in a world that expresses in activities, interests and opinions. Lifestyle influences one's behaviour which ultimately determines one's consumer pattern [5]. Lifestyle is a person's behaviour in showing the pattern of life that is reflected in the activities, interests, and income [6]. The lifestyle concept if used carefully 
in marketing, it can help to understand if these values affect consumer behaviour.

Lifestyle is defined more broadly as a way of life that is identified by how people spend their time (activities), what they consider important in their environment (interest), and what they think about themselves as well as the world around them (opinions). Lifestyle describes the "whole person" in interacting with the environment [7]. The Categories of lifestyle: (1) Normative lifestyle. It describes the hopes that culture imposed on individuals by their societies and refers to the economic value system and the consumption of a society of values and attitudes of the economic development stage of the law and its relations. (2) Personal Lifestyle. It refers to individual beliefs about consumption activity within their culture and subculture communities.

The social change is necessary because of the intrinsic nature of social behaviours. This means that because humans interact with each other and because of the motion and purpose of social ties, then the social changes that are needed [8].

The concept of social change can be divided into two, namely as follows:

\section{A. The Occurrence of Social Change}

The concept of social change is one way to present diverse empirical events or phenomena, which are important, in the generalization process of social change.

\section{B. Characteristics of social change}

- The advancement in science and technology drive of ideological, political and economic thinking.

- Mobility with the occurrence of industrial revolution and democratic revolution, there is also mobility both horizontal and vertical.

- Pertentangan Conflict may also be the cause of social change. Opposition may occur between individuals with groups or group intermediaries with groups.

There are factors that affect of lifestyle, namely internal factors and external factors [9]. The combination of these factors will make a person experiencing a tendency with his lifestyle, whichever is more dominant are as follows:

\section{1) Internal factors}

a) Attitude: Attitude means a state of mind and state of mind prepared to respond to an object that is organized through experience and directly affects behavior.

b) Experience and observation: Experience can influence social observations in behavior, experience can be gained from all past actions and can be learned, through learning people will gain experience.

c) Personality: Personality is the configuration of individual characteristics and ways of behaving that determine the behavioral differences of each individual.

d) Self-concept: Self-concept has become a widely recognized approach to describe the relationship between consumer self-concept and brand image. e) Motives: Individual behavior arises because of the motive needs to feel secure and the need for prestige are some examples of motives.

f) Perception: Perception is the process by which a person chooses, organizes, and interprets information to form a meaningful picture of the world.

\section{2) External factors}

a) Reference group: Reference groups are groups that have a direct or indirect influence on one's attitudes and behavior.

b) Family: The family holds the greatest and longest role in the formation of individual attitudes and behaviors.

c) Social class: Social class is a relatively homogeneous and lasting group within a society, arranged in a sequence of levels, and members in each level have the same values, interests, and behaviors.

\section{METHOD}

This research uses qualitative approach with case study strategy. Qualitative research thus refers to the meanings, concepts, definitions, characteristics, metaphors, symbols, and descriptions of things [10]. The reason for choosing qualitative approaches in order to explain the case more deeply. Qualitative case studies as research using empirical evidence from one or more organizations and researchers try to learn the problem from the context [11]. Case study research divided in three type that is explanatory, exploratory, and descriptive [12]. This study uses an explanatory case study with the consideration that explanatory case studies will be useful when used in cause-and-effect studies, especially in complex societal or organizational research, want a consideration for using a variety of cases to test some of the effects.

The research location of Tellulimpoe Village, Tellulimpoe District, Sinjai. To obtain data both primary and secondary, the target of this research is focused on the change of social lifestyle of rural community. The study was conducted for three months from July to September 2017. Data collection through in-depth interviews, observation, and documentation. To validity of data used triangulation of sources and method. While the data analysis used interactive analysis technique which includes data collection, reduction, data presentation, and conclusion [13].

\section{RESULT AND DISCUSSION}

The lifestyle changes of Tellulimpoe village show how people manage their private lives, public life, public behavior, and differentiate their status from others through social institutions. Today's society is synonymous with traditional, innocent, simple society. Modern impression is far from their image as a native now. Deliberate developments in the field take place nowadays either directly or indirectly demanding the community to be able to adapt to various forms of change and renewal. Now the population is experiencing various changes after the television. 


\section{A. Understanding Tellulimpoe Society Against Television}

The development of telecommunication technology, especially television increasingly shows the rapid growth of consumers or audience was introduced to various events, such as news, operas, movies, and so forth. The use of television cannot be separated from the increasing public demand for information and entertainment facilities, including children. The Tellulimpoe community generally likes television media in other media appeals. Those who like the television media consider television as a means of entertainment, knowledge, and information center. Here, television is considered as one of the electronic media that uses pictures and sound. The way the presentation is short and easy to understand makes they like to watch television and make it as a means of entertainment, because it presents a variety of events, such as operas, news, D'Academy, Pesbuker, and so forth. In addition, television is also one of the media of communication, because the television is able to provide a message, and the audience received the message well. The way the presentation of television information is easy to understand makes people more interested in television media than other media.

\section{B. Impacts of Using Television for Tellulimpoe Society}

Television is considered as one of the media that makes the students or children lazy to learn. When a child has been presented to watch his favorite, instead they are lazy to learn. This is what affects the behavior of children. In fact, they often late for school when the night watching television. Their world should be spent by learning, not by playing or watching. In addition to negative impacts, television has also had a positive impact. Seen when some station of the appearance of a bright and accomplished child. When children see events that show a smart child, make this child more studious learning, because they hope someday they can become like them. The forms of television influence themselves vary, some are negative and some are positive, depending on how they digest from what they see on television. From what they see, then they respond and determine the attitude or action. The influence of the behavior of children or students is also influenced by the socialization agent, one of the media agents. Events that aired on television such as violent films will lead to aggressive behavior such as following the trend. While the impressions that display science will lead to a better mindset such as adding knowledge of science.

\section{Factors that Affect Change in Social Lifestyle of Tellulimpoe Society}

Social changes that occur in other common people are always influenced by two factors that come from the community and from outside the community (internal factors and external factors). The tendency of social changes is a natural phenomenon arising from the interaction of human life in society. Social changes will continue as long as there is interaction between people and the community. Social change occurs because of changes in maintaining elements of community balance, such as changes in geographical, economic, biological, and cultural elements. The changes are made to adjust to the dynamic times. To analyze the factors that influence the social lifestyle changes in Tellulimpoe, we need to pay attention to some of the factors driving the process of social change, and some of them are as follows:

- The existence of a good formal education system.

- The value that humans must constantly seek to improve their life.

- Open society system (open stratification).

- An open attitude to the work and the desire of others to move forward.

- Tellulimpoe community discontent against the field of life.

The social changes that occur in Tellulimpoe society are not separated by the interaction with other cultures of society, the determination of these factors supports the theory of social change in terms of assimilation (interaction between cultures) inter-cultural interaction, and assimilation is defined as the process social issues arising out of existence:

- Different human groups of cultures.

- The individuals as members of the group get along with each other directly and intensively for a relatively long time.

- The cultures of the human group each change and adjust to each other. Usually the groups referred to in a process of assimilation are a majority and some minority groups.

Basically, social contact with the local community that brought many changes from within (internal) community of Tellulimpoe Village is in line with the understanding that the individual is a reflection of the material state of their lives. The theoretical thus implies that humans are easily formed (plastic) creatures formed by their social environment and if there is a human nature there is very little but it is also important for our understanding of social change [14].

\section{CONCLUSIONS}

Based on the description that has been presented in the form of the results of the discussion of data and information that has been obtained in the research location, it can be concluded as follows:

With the existence of television to this community resulted a small change that does not bring a direct or meaningful effect for the community such as changing dress / dress style in the community in Tellulimpoe Village that has started to follow the trend. This society has a view or opinion that television is one electronic media that uses pictures and sound. In addition, television is also one of the more updated media, so it is not outdated and many provide information and entertainment facilities.

Through a variety of impressions, it turns the television has a positive and negative impact. The positive impact of these children has a passion for learning and becoming a successful person. While the negatives are these children are lazy to learn. With the existence of a formal education system that has advanced to the community, the existence of an open system of 
society, the attitude of open to the work and the desire of others to move forward.

\section{REFERENCES}

[1] Sunarno, Globalization and information technology: forging new partnerships in public administration Asian Rev. Public Adm. XII, 2, 2001.

[2] Ceulemans $\mathrm{P}$ W, The impact of technology on social behavior Wisconsin Stout University. 2012

[3] Kheeshadeh M, Effects of globalization on mass media in the world I. J Asian Social Sci. IJASS 02(2007)1742. 2007

[4] Fairclough, N. Discourse and Social Change. Discourse 54, 259, 1992.

[5] Martin, F., Lewis, T. \& Sinclair, J. Lifestyle Media and Social Transformation in Asia. Media International Australia 147, 51-61 2013.
[6] Tomlinson, M. Lifestyle and Social Class. European Sociological Review 19, 97-111, 2003.

[7] Jackson, T. The Challege of Sustainable Lifestyles. 2008 State of the world - innovations for a sustainable economy 45-60, 2008.

[8] Shochat, T. Impact of lifestyle and technology developments on sleep. Nature and Science of Sleep 4, 19-31, 2012.

[9] Featherstone, M. Lifestyle and Consumer Culture. Theory, Culture \& Society 4, 55-70, 1987.

[10] Berg B L, Qualitative Research Methods for Social Sciences (Boston: Pearson Publications). 2007.

[11] Myers M, Qualitative Research In Business \& Management (London: Sage Publications). 2009.

[12] Yin R K. Case Study Research : Design and Methods (London: Sage Publications) 2013.

[13] Miles M B, Huberman A M, Saldana J, Qualitative Data Analysis (London: Sage Publications), 2013.

[14] Jackson, T. Lifestyle Change and Market Transformation. Journal of Social Issues (p. 47). 2005. 